\title{
Inokulasi Cendawan Fusarium sp. dari Berbagai Tanaman Inang dan Diameter Batang terhadap Pembentukan Kemedangan Gaharu Jenis Gyrinophs versteegii
}

\section{Inoculation of Fusarium sp. from Various Host Plants and Stems Diameter to Forming Kemedangan Agarwood Type Gyrinophs versteegii}

\author{
Faishal Irfandi $^{1 *}$, Bambang Hermiyanto ${ }^{1}$, dan Raden Soedradjad ${ }^{1}$ \\ ${ }^{1}$ Program Studi Agroteknologi, Fakultas Pertanian, Universitas Jember \\ Jln. Kalimantan 37, Kampus Tegal Boto, Jember 68121 \\ *E-mail: faishalirfandi93@yahoo.com
}

Diterima 27 Desember 2016/Disetujui 3 Maret 2017

\begin{abstract}
Infectivity and effectivity the fungus of Fusarium sp. in the formation of "kemedangan" agarwood can be affected by the type of isolates and age of plant. The aim of this study is to know the effectivity of fungi Fusarium sp. from various host plants against the establishment of "kemedangan" on various rod diameters of Gyrinophs versteegii. This study apply random design on group using nine (9) treatments repeated 3 times, so that there are 27 treatments of plants. The treatments used are isolates sourced from Banana + plants having rods diameter $<3 \mathrm{~cm}\left(I_{1}\right)$, isolates sourced from Banana + plants having rods diameter between 3 to $4 \mathrm{~cm}\left(I D_{2}\right)$, isolates sourced from Banana + plants having rods diameter $>4 \mathrm{~cm}\left(I D_{3}\right)$, isolates sourced from Eggplant + plants having rods diameter $<3 \mathrm{~cm}\left(\mathrm{ID}_{4}\right)$, isolates sourced from Eggplant + plants having rods diameter between 3 to $4 \mathrm{~cm}\left(I_{5}\right)$, isolates sourced from Eggplant + plants having rods diameter $>4 \mathrm{~cm}\left(I D_{6}\right)$, isolates sourced from Tomato + plants having rods diameter $<3 \mathrm{~cm}\left(\mathrm{ID}_{7}\right)$, isolates sourced from Tomato + plants having rods diameter between 3 to $4 \mathrm{~cm}\left(I D_{8}\right)$, isolates sourced from Tomato + plants having rods diameter $>4 \mathrm{~cm}\left(I D_{9}\right)$. Inoculation technique used on agarwood rods is injecting inoculation technique. Variable used in this study is the area of plant tissues infected (on score), the color of plant tissues infected (on score), the levels of "kemedengan" scent (on score), and the levels of astiri oil. The result of this study indicates that the effectivity of Boletus Fusarium sp. from various hos plants to the establishment of "kemedangan" on various rod diameters of Gyrinophs versteegii is absolutely impact to the area of plant tissues infected and to the color of plant tissues infected. ID 3 is the best treatment because applying to the rods, which have diamater more than 4 $\mathrm{cm}$.
\end{abstract}

Keywords: Agarwood,Fusarium sp., Gyrinophs versteegii

\section{ABSTRAK}

Infektivitas dan efektivitas cendawan Fusarium sp. dalam pembentukan kemedangan gaharu dapat dipengaruhi oleh jenis isolat dan umur tanaman. Tujuan dari penelitian ini untuk mengetahui tingkat efektivitas cendawan Fusarium sp. dari berbagai tanaman inang terhadap pembentukan kemedangan pada berbagai diameter batang tanaman Gyrinophs versteegii. Penelitian menggunakan rancangan acak kelompok (RAK) dengan 9 perlakuan yang diulang 3 kali sehingga terdapat 27 perlakuan tanaman. Perlakuan yang diberikan adalah tanaman inang pisang + diameter $<3 \mathrm{~cm}\left(I D_{1}\right)$, tanaman inang pisang + diameter 3-4 cm $\left(I D_{2}\right)$, tanaman inang pisang + diameter $>4 \mathrm{~cm}\left(\mathrm{ID}_{3}\right)$, tanaman inang terong + diameter $<3 \mathrm{~cm}\left(\mathrm{ID}_{4}\right)$, tanaman inang terong + diameter $3-4 \mathrm{~cm}\left(I_{5}\right)$, tanaman inang terong + diameter $>4 \mathrm{~cm}\left(I_{6}\right)$, tanaman inang tomat + diameter $<3 \mathrm{~cm}\left(I D_{7}\right)$, tanaman inang tomat + diameter $3-4 \mathrm{~cm}\left(I D_{8}\right)$, dan tanaman inang tomat + diameter $>4 \mathrm{~cm}\left(\mathrm{ID}_{9}\right)$. Teknik inokulasi pada batang tanaman gaharu menggunakan teknik inokulasi injeksi (suntik). Variabel penelitian yang digunakan adalah luas jaringan terinfeksi ( $\left.\mathrm{cm}^{2}\right)$, warna jaringan terinfeksi (dalam skoring), tingkat aroma kemedangan (dalam skoring) dan analisis kadar minyak atsiri. Hasil penelitian menunjukkan bahwa pengaruh cendawan Fusarium sp. dari berbagai tanaman inang terhadap pembentukan kemedangan gaharu pada berbagai diameter batang tanaman memberikan pengaruh nyata terhadap variabel luas jaringan terinfeksi dan warna jaringan terinfeksi. ID ${ }_{3}$ adalah perlakuan yang menunjukkan terbaik dari seтиa perlakuan yang diaplikasikan disebabkan diameter batang lebih dari $4 \mathrm{~cm}$.

Kata kunci: Fusarium sp., Gaharu, Gyrinophs verstegii

\section{PENDAHULUAN}

Gaharu merupakan substansi aromatik yang berupa gumpalan resin yang terdapat diantara sel-sel kayu dengan 
berbagai bentuk dan warna yang khas serta memiliki kandungan resin berbau wangi, yang berasal dari pohon atau bagian pohon penghasil gaharu sebagai akibat dari proses infeksi mikroba baik secara alami maupun buatan (Syukur dan Muda, 2015). Mekanisme pembentukan gaharu, menurut Isnaini (2008) merupakan suatu respon terhadap infeksi mikroba melalui 3 (tiga) hipotesis, yaitu (1) patologi, (2) pelukaan dan patologi, dan (3) non-patologi. Berdasarkan hasil penelitian Isnaini (2008), menyebutkan bahwa tidak semua jenis cendawan mampu menginduksi pembentukan gaharu. Pembentukan gaharu dapat dipengaruhi oleh pelukaan, masuknya cendawan yang menginfeksi (Isnaini, 2008), dan cara penyuntikan inokulan (Syukur dan Muda., 2015). Dalam suatu proses pembentukan gaharu bahwa semakin lama waktu proses akan menyebabkan warna pada daerah infeksi menjadi gelap (Herawati, et. al., 2010).

Berdasarkan uraian diatas, maka penelitian yang dilakukan adalah mengkaji efektifitas cendawan Fusarium $s p$. dari berbagai tanaman inang terhadap pembentukan kemedangan gaharu pada berbagai diameter batang tanaman Gyrinophs versteegii. Sehingga penelitian ini bertujuan untuk mengetahui pengaruh cendawan Fusarium sp. yang berasal dari berbagai tanaman inang terhadap pembentukan kemedangan gaharu pada berbagai diameter batang tanaman Gyrinophs versteegii.

\section{BAHAN DAN METODE}

\section{Persiapan Penelitian}

Alat dan bahan yang digunakan selama penelitian antara lain: bor listrik dan mata bor kayu ukuran $2 \mathrm{~mm}$ dan 4 mm, penggaris, suntikan, mikroskop, LAF (Laminar Air Flow), haemacytometer, isolat cendawan Fusarium sp. yang didapatkan dari tanaman budidaya yang terserang gejala penyakit layu Fusarium (pisang, terong, tomat), tanaman penghasil gaharu jenis Gyrinophs versteegii yang memiliki diameter kurang dari $3 \mathrm{~cm}$, antara 3 sampai $4 \mathrm{~cm}$ serta lebih dari $4 \mathrm{~cm}$, Potato Dextrosa Agar (PDA) dan alkohol $75 \%$.

\section{Pelaksanaan Penelitian}

Penelitian kali ini merupakan percobaan dengan rancangan dasar acak kelompok (RAK) dengan 9 perlakuan, yang terdiri dari: tanaman inang pisang + diameter $<3 \mathrm{~cm}$ $\left(\mathrm{ID}_{1}\right)$, tanaman inang pisang + diameter $3-4 \mathrm{~cm}\left(\mathrm{ID}_{2}\right)$, tanaman inang pisang + diameter $>4 \mathrm{~cm}\left(\mathrm{ID}_{3}\right)$, tanaman inang terong + diameter $<3 \mathrm{~cm}\left(\mathrm{ID}_{4}\right)$, tanaman inang terong + diameter 3-4 cm ( $\left.\mathrm{ID}_{5}\right)$, tanaman inang terong + diameter $>$ $4 \mathrm{~cm}\left(\mathrm{ID}_{6}\right)$, tanaman inang tomat + diameter $<3 \mathrm{~cm}\left(\mathrm{ID}_{7}\right)$, tanaman inang tomat + diameter 3-4 $\mathrm{cm}\left(\mathrm{ID}_{8}\right)$, dan tanaman inang tomat + diameter $>4 \mathrm{~cm}\left(\mathrm{ID}_{9}\right)$ yang kemudian diulang 3 kali sehingga terdapat 27 perlakuan.

\section{Isolasi Jamur}

Proses isolasi diawali dengan mendapatkan isolat Fusarium sp. dari tanaman inang tanaman budidaya pisang, terong, dan tomat. Isolat tersebut didapatkan dengan cara melakukan isolasi terhadap sampel tanaman budidaya pisang, terong dan tomat yang terdapat gejala penyakit layu Fusarium. Setelah didapatkan isolat murni dari masingmasing tanaman inang, kemudian dilakukan pengamatan secara makroskopis dan mikroskopis. Isolat murni dari 3 tanaman inang yang memiliki warna dasar koloni yang berbeda-beda. Pada tanaman inang yang berasal dari tanaman pisang, memiliki warna dasar koloni berwarna merah muda dengan bentuk makrokonidida seperti bulan sabit dengan 3-4 sekat. Sama halnya dengan isolat Fusarium $s p$. yang berasal dari tanaman tomat, namun memiliki warna dasar koloni berwarna ungu. Lain halnya isolat Fusarium sp. yang berasal dari tanaman inang terong memiliki warna dasar koloni putih keunguan dengan terdapat mikrokonidia yang memiliki 1-2 sekat.

\section{Persiapan SuspensiFusarium sp.}

Pembuatan suspensi Fusarium dengan menuangkan sebanyak $10 \mathrm{ml}$ aquades kedalam isolat jamur media agar miring. Suspensi di tetesi larutan tween dengan menggunakan pipet sebanyak 1 tetes setelah itu di vortex hingga homogen untuk mempermudah agar konidia larut dalam air. Setelah itu cendawan dikerik dengan menggunakan jarum ose steril hingga semua konidia cendawan terlepas dari permukaan media, lalu menghomogenkan suspensi konidia tersebut dengan cara di vortex selama 3 menit.

\section{Penghitungan Spora}

Penghitungan kerapatan spora pada penelitian ini menggunakan standar agensia hayati yaitu $10^{6} \mathrm{spora} / \mathrm{ml}$. Kerapatan spora ini dihitung dengan menggunakan alat Haemacytometer Naubauer, kemudian hasil yang diperoleh dihitung dengan menggunakan rumus.

\section{Uji Patogenisitas}

Uji patogenisitas cendawan pada bibit tanaman gaharu jenis Gyrinophs versteegii dengan menggunakan kerapatan spora $10^{6} \mathrm{spora} / \mathrm{ml}$.. Pengamatan hasil uji patogenisitas ini dilakukan dengan cara mengoleskan pada batang tanaman gaharu yang telah dikuliti kulit batangnya. Pengamatan yang telah di lakukan menunjukkan bahwa bibit tanaman gaharu yang memperlihatkan perubahan warna pada bagian batang tanaman yang telah dilukai

\section{PerbanyakanFusarium sp.Pada Media Cair Ekstrak Kentang Gula (EKG).}

Perbanyakan dilakukan dengan cara membuat media ekstrak kentang gula (EKG) terlebih dahulu. Setelah media EKG siap dan telah di sterilisasi, isolat yang telah murni kemudian diambil menggunakan ose yang kemudian dimasukkan kedalam Erlenmeyer ukuran $100 \mathrm{ml}$ yang didalamnya telah terdapat media cair EKG sebanyak $75 \mathrm{ml}$. Proses ini dilakukan di dalam LAF pada kondisi steril. 
Setelah itu, isolat yang terdapat di dalam Erlenmeyer kemudian di shaker dengan kecepatan 100 rpm selama 5 hari.

\section{Inokulasi CendawanFusarium sp. PadaTanaman Gyrinophs versteegii}

Rekayasa teknologi dengan metode injeksi (suntik) dilakukan dengan cara sebagai berikut: membuat titik-titik dengan spidol pada batang tanaman yang akan dilubangi dengan jarak lubang $20 \mathrm{~cm}$ dari permukaan tanah, jarak lubang ke samping $15 \mathrm{~cm}$ dan jarak lubang ke atas $20 \mathrm{~cm}$, titik yang ditandai dilubangi dengan kedalaman 1/3 dari diameter batang tanaman dengan arah dari atas ke bawah (kemiringan $30^{\circ}$ ). Pembuatan lubang inokulasi dilakukan sebanyak 5 lubang setiap pohon sebanyak 27 pohon, kemudian menyuntikkan inokulan Fusarium sp. ke dalam lubang inokulasi sebanyak $1 \mathrm{ml}$ pada setiap lubang, tutup lubang inokulasi dengan menggunakan plastisin sehingga lubang inokulasi tertutup rapat agar tidak terdapat mikroorganisme atau binatang kecil yang masuk ke dalam lubang inokulasi, dan dilakukan pengulangan penyuntikkan inokulasi setiap satu minggu sekali selama 90 hari dengan pada setiap pelaksanaan inokulasi dilakukan pengamatan.

\section{Variabel pengamatan}

Pengukuran Luas Jaringan Terinfeksi (dalam $\mathrm{cm}^{2}$ ), uji organoleptik warna jaringan terinfeksi (dalam skor)tingkat perubahan warna kayu ditetapkan berdasarkan sistem skor $(0=$ putih, $1=$ putih kecoklatan, $2=$ coklat, $3=$ coklat kehitaman),uji organoleptik aroma kemedangan (dalam skor)skala skor pada tingkat keharuman kemedangan adalah 0 = tidak beraroma standart gaharu, $1=$ aroma standart gaharu tipis, 2 = aroma sama dengan standart gaharu, 3 = aroma lebih tajam dengan standart gaharu, dan 4 = aroma sangat tajam dengan standar gaharu, dan analisis kadar minyak atsiri gaharu

\section{Analisis Data}

Data dianalisis menggunakan analisis ragam (ANOVA). Apabila terdapat perbedaan yang nyata, maka dilanjutkan dengan uji jarak berganda Duncan pada taraf $5 \%$.

\section{HASIL DAN PEMBAHASAN}

\section{Hasil}

Perubahan fisik yang terjadi yaitu berupa klorosis pada daun-daun tanaman yang terletak dekat dari daerah inokulasi. Peristiwa klorosis terjadi pada sebagian daun tanaman gaharu yang terjadi hampir pada semua tanaman perlakuan sehingga hal ini menunjukkan perbedaan perubahan fisik yang terjadi sebelum inokulasi cendawa dilakukan dan setelah inokulasi cendawan. Pada 30 hsi hanya terjadi pada sebagian daun tanaman tua seperti yang terlihat pada Gambar 1. Namun, pada 50 hsi terjadinya klorosis terjadi memenuhi seluruh helai daun. Terjadinya klorosis ini terjadi pada hampir semua kombinasi perlakuan. Selain itu, tanaman yang mengalami klorosis tersebut sudah mulai terjadi gugur daun.

Selain kondisi tanaman yang dapat mempengaruhi pembentukan gaharu, kandungan unsur hara tanah dapat mempengaruhi keberhasilan inokulasi. Hasil analisis unsur hara tanah pada Tabel 1, menunjukkan bahwa tingkat kesuburan dari tempat tumbuh tanaman sangat tinggi. Hasil analisis $\mathrm{N}$ total tergolong sedang pada kedua lokasi sampel tanah, yaitu $0.26 \%$ pada sampel lokasi atas dan $0.35 \%$ pada lokasi sampel tanah bawah.

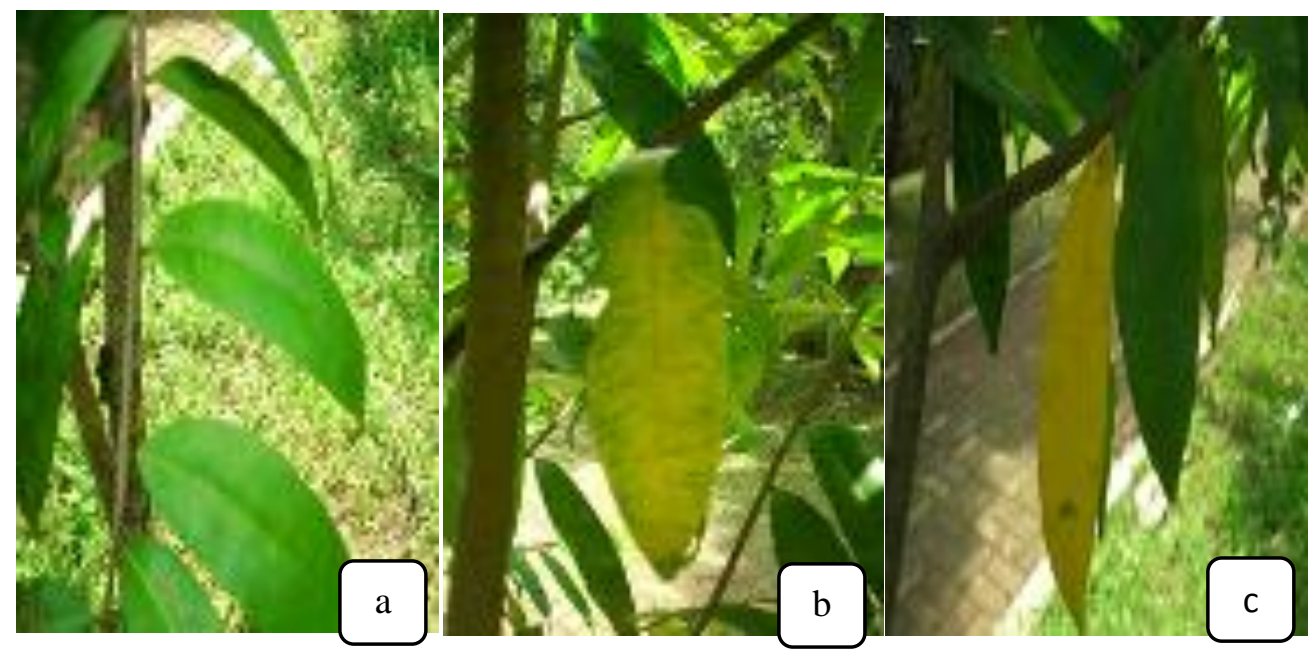

Gambar 1. Perubahan fisik tanaman G. versteegii; sebelum inokulasi (a) dan setelah 30 hsi (b) dan 50 hsi (c). 
Tabel 1 Hasil analisis tanah (N, P, K, C-Organik, pH, C/N)

\begin{tabular}{|c|c|c|c|c|c|c|c|c|}
\hline \multirow[b]{2}{*}{ No. } & \multirow{2}{*}{$\begin{array}{c}\text { Lokasi } \\
\text { Pengambilan } \\
\text { Sampel Tanah } \\
\end{array}$} & \multirow[b]{2}{*}{$\begin{array}{l}\text { Elevasi } \\
\text { (mdpl) }\end{array}$} & \multicolumn{6}{|c|}{ Parameter } \\
\hline & & & N-Total (\%) & $\begin{array}{c}\text { P-Bray } \\
(\mathrm{ppm})\end{array}$ & $\begin{array}{c}\text { K-Tersedia } \\
(\mathrm{ppm})\end{array}$ & C-Org (\%) & $\mathrm{pH}$ & $\mathrm{C} / \mathrm{N}(\%)$ \\
\hline 1. & Taman Botani & 417 & $\begin{array}{c}0.26 \\
(\mathrm{~S})\end{array}$ & $\begin{array}{l}43.78 \\
(\mathrm{ST})\end{array}$ & $\begin{array}{c}383.69 \\
(\mathrm{ST})\end{array}$ & $\begin{array}{l}1.24 \\
(\mathrm{R})\end{array}$ & $\begin{array}{c}5.88 \\
(\mathrm{AM})\end{array}$ & $\begin{array}{l}4.77 \\
\text { (SR) }\end{array}$ \\
\hline 2. & Sukorambi & 322 & $\begin{array}{l}0.35 \\
(\mathrm{~S})\end{array}$ & $\begin{array}{l}13.71 \\
(\mathrm{ST})\end{array}$ & $\begin{array}{c}232.30 \\
(\mathrm{ST})\end{array}$ & $\begin{array}{l}0.65 \\
(\mathrm{SR})\end{array}$ & $\begin{array}{c}6.27 \\
(\mathrm{AM})\end{array}$ & $\begin{array}{l}1.86 \\
(\mathrm{SR})\end{array}$ \\
\hline
\end{tabular}

Keterangan : Sangat Rendah; R= Rendah; $\mathrm{S}=$ Sedang; $\mathrm{T}=$ Tinggi; $\mathrm{ST}=$ Sangat Tinggi; AM= Agak masam; (Balai Penelitian Tanah, 2009).

Tabel 2 Hasil pengamatan berdasarkan variabel penelitian

\begin{tabular}{llc}
\hline No. & Variabel Penelitian & Nilai F-Hitung \\
\hline 1. & Luas Jaringan Terinfeksi $\left(\mathrm{cm}^{2}\right)$ & $11.83 * *$ \\
2. & Warna Jaringan Terinfeksi (skoring) & $10.14 * *$ \\
3. & Tingkat Aroma Kemedangan (skoring) & $1.88 \mathrm{~ns}$ \\
\hline
\end{tabular}

Keterangan : Berbeda tidak nyata (ns) dan berbeda sangat nyata (**); Nilai dari masing-masing variable penelitian diperoleh dalam masa 90 hari setelah inokulasi.

Pada analisa $\mathrm{K}$ tersedia menunjukkan hasil analisa tanah sangat tinggi pada sampel lokasi atas dengan nilai $383.69 \mathrm{ppm}$ dan nilai hasil analisa tinggi pada sampel lokasi bawah sebesar $232.30 \mathrm{ppm}$. Hasil analisis unsur P tersedia menunjukkan bahwa kadar $\mathrm{P}$ yang tersedia di dalam tanah menunjukkan kadar yang sangat tinggi pada sampel lokasi atas dengan nilai $43.78 \mathrm{ppm}$ sedangkan kadar $\mathrm{P}$ tersedia sedang ditunjukkan pada sampel tanah bagian bawah dengan nilai 13.71 ppm. Namun, berbeda halnya dengan hasil analisis C-organik rendah pada sampel lokasi atas dengan nilai $1.24 \%$ dan pada sampel tanah lokasi bawah memiliki kadar C-organik sangat rendah dengan nilai $0.65 \%$. Hasil pengukuran sifat kimia tanah diatas, menunjukkan bahwa tingkat kesuburan tanah pada lokasi penelitian yang ditanam tanaman gaharu jenis Gyrinophs versteegii memiliki tingkat kesuburan tanah yang berbeda-beda. Hal ini sangat berpengaruh pada proses pembentukan kemedangan gaharu yang terjadi di dalam tanaman akibat perlawanan sistem kekebalan tanaman terhadap serangan infeksi patogen yang masuk kedalam jaringan tubuh tanaman.

Hasil pengamatan berdasarkan variabel penelitian yang diantaranya luas jaringan terinfeksi, warna jaringan terinfeksi dan tingkat aroma kemedangan yang kemudian data-data tersebut dirangkum berdasarkan nilai F-hitung dengan taraf kepercayaan 5\% pada masing-masing perlakuan yang ditampilkan pada Tabel 2 .

Terjadinya infeksi pada tanaman gaharu sebagai akibat masuknya mikroorganisme, sehingga pembentukan gubal gaharu dapat menyebar pada bagian batang tanaman G. versteegii. Arah penyebaran infeksi tersebut seperti yang terlihat pada Gambar 2.

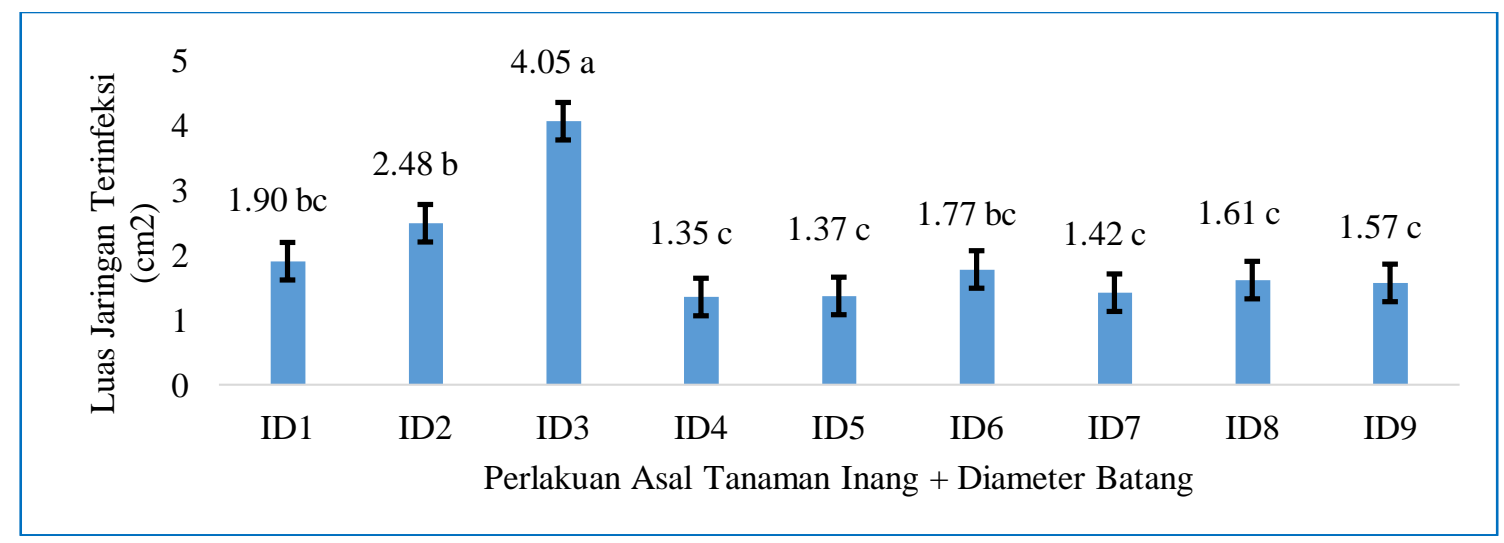

Gambar 2. Luas jaringan terinfeksi pada berbagai perlakuan 


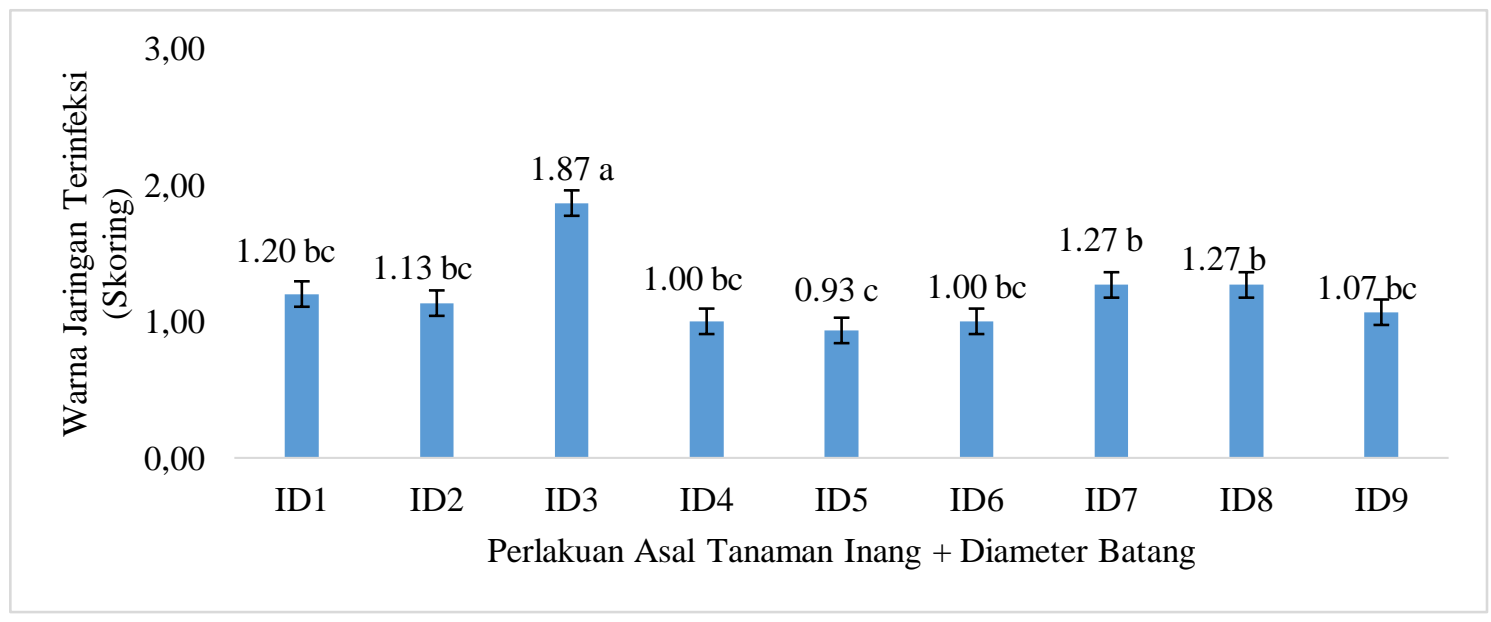

Gambar 3. Warna jaringan terinfeksi gaharu pada tiap perlakuan

Terdapat pengaruh sangat nyata terhadap perlakuan antara asal inang dengan berbagai diameter batang yang berbeda. Perlakuan terbaik yaitu pada perlakuan asal inang pisang yang diaplikasikan pada diameter batang gaharu lebih dari 4 $\mathrm{cm}\left(\mathrm{ID}_{3}\right)$ dengan rata-rata luas infeksi sebesar $4.05 \mathrm{~cm}^{2}$, sedangkan perlakuan terendah terjadi pada perlakuan dengan tanaman inang terong yang diaplikasikan pada diameter batang tanaman kurang dari $3 \mathrm{~cm}\left(\mathrm{ID}_{4}\right)$ dengan rata-rata luas infeksi sebesar $1.35 \mathrm{~cm}^{2}$. Pada variabel penelitian luas jaringan terinfeksi ini terdapat perbedaan yang nyata pada perlakuan tanaman inang pisang dan diameter batang lebih dari $4 \mathrm{~cm}\left(\mathrm{ID}_{3}\right)$ dengan semua perlakuan.

Mikroba, seperti halnya Fusarium sp. yang menginfeksi tanaman penghasil gaharu jenis Gyrinops versteegii dapat merangsang perubahan warna kayu yang diakibatkan karena adanya senyawa terpenoid sebagai indikator efektifitas dan interaksi antara mikroba dengan tanaman dalam pembentukan gubal gaharu pada gambar 3 .

Kategori warna rata-rata skor pada gambar 3 diatas, terletak antara warna putih hingga putih kecoklatan. Pada gambar 3 membuktikan bahwa perlakuan terendah pada variabel

Penelitian warna jaringan terinfeksi terjadi pada perlakuan $\mathrm{ID}_{5}$ yaitu pada isolat terongdan aplikasi pada diameter batang antara $2 \mathrm{~cm}$ sampai $3 \mathrm{~cm}$ dengan rata-rata nilai skor 0.93 yang masuk pada kategori warna putih.

Namun, rata-rata skor terbaik terjadi pada kombinasi perlakuan $\mathrm{ID}_{3}$ dengan perlakuan berupa tanaman inang pisang dan diameter batang tanaman lebih dari $4 \mathrm{~cm}$ dengan rata-rata nilai skor sebesar 1.87 yang tergolong kategori warna putih kecoklatan

. Pada variabel penelitian warna jaringan terinfeksi ini perlakuan $\mathrm{ID}_{3}$ menunjukkan kombinasi perlakuan yang berbeda nyata dengan seluruh perlakuan lainnya. Perubahan warna jaringan yang terinfeksi akibat adanya mikroba yang masuk ke dalam tubuh tanaman tersebut, menyebabkan kayu gaharu tersebut muncul aroma yang wangi. Seperti yang terlihat pada gambar 4 berikut ini.

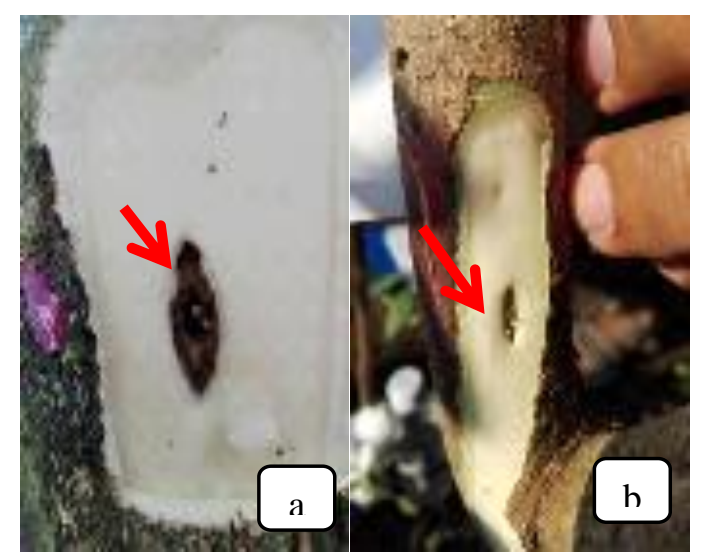

Gambar 4. Luas jaringan terinfeksi isolat menunjukkan adanya gejala pembentukan gaharu pada kombinasi perlakuan $\mathrm{ID}_{3}$ (a) dan $\mathrm{ID}_{4}(\mathrm{~b})$. 


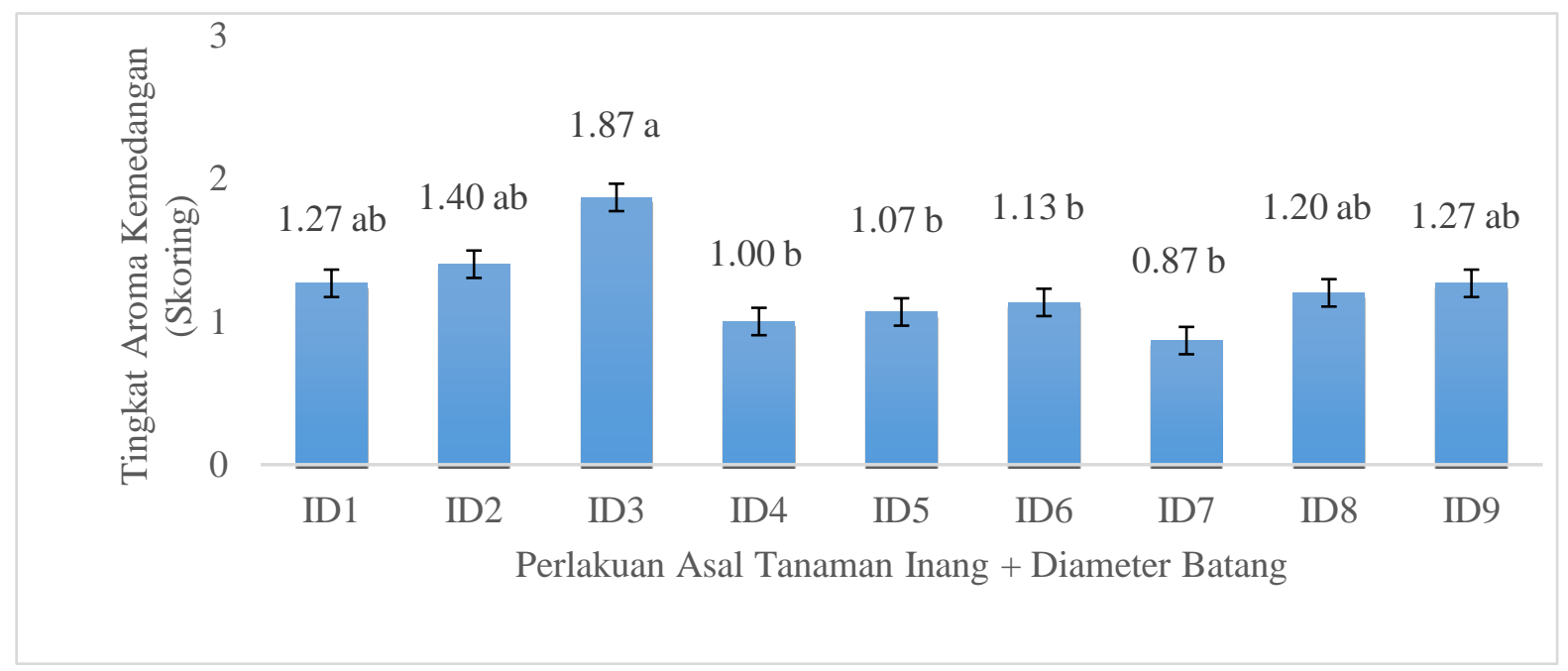

Gambar 5. Aroma kemedangan gaharu pada berbagai perlakuan

Berdasarkan pada gambar 5, menunjukkan bahwa pada variabel tingkat aroma kemedangan gaharu tidak memberikan pengaruh yang signifikan pada semua perlakuan yang diujikan. Pada perlakuan $\mathrm{ID}_{3}$ menunjukkan nilai rata-rata perlakuan 1.87 , tetapi nilai tersebut menunjukkan tidak berbeda nyata dengan perlakuan $\mathrm{ID}_{1}$, $\mathrm{ID}_{2}, \mathrm{ID}_{8}$ dan $\mathrm{ID}_{9}$. Namun, berbeda nyata jika dibandingkan dengan $\mathrm{ID}_{4}, \mathrm{ID}_{5}, \mathrm{ID}_{6}$, dan $\mathrm{ID}_{7}$. Sehingga berdasarkan gambar 5 tersebut tingkat aroma kemedangan menunjukkan pengaruh yang tidak signifikan terhadap semua perlakuan yang diberikan.

Mikroba yang diinokulasikan ke dalam tanaman sehingga mengakibatkan adanya penyebaran luas jaringan terinfeksi serta adanya perubahan warna kayu tersebut, maka terdapat senyawa-senyawa kimia yang keluar dari dalam tubuh tanaman dan senyawa tersebut tergolong ke dalam bagian minyak atsiri gaharu. Minyak atsiri tersebut, muncul akibat adanya mikroba yang masuk ke dalam jaringan tanaman sehingga tanaman tersebut mengeluarkan zat imun. Kadar minyak atsiri yang keluar pada tanaman G. versteegii dapat ditunjukkan pada hasil analisis pada Tabel 3.

Berdasarkan hasil analisis yang telah dilakukan, menunjukkan bahwa sampel batang gaharu yang di uji sebanyak < 100 ppm (25 ppm berdasarkan komunikasi pribadi). Hasil tersebut jika dikonversi dengan persen setara dengan $0.01 \%$

\section{Pembahasan}

Terjadinya klorosis ini terjadi pada hampir semua kombinasi perlakuan. Selain itu, tanaman yang mengalami klorosis tersebut sudah mulai terjadi gugur daun. Perubahan fisik yang terjadi dengan ditunjukkan adanya peristiwa klorosis ini diduga diakibatkan karena adanya pengeboran yang terjadi pada batang tanaman serta diduga akibat infeksi mikroba yang masuk kedalam jaringan tanaman sehingga dapat menghambat distribusi nutrisi pada tanaman. Menurut Agrios (2004) cendawan dapat menyebabkan klorosis dengan cara memanfaatkan nutrisi inang untuk perkembangan dan metabolisme.

Pada variabel penelitian luas jaringan terinfeksi ini terdapat perbedaan yang nyata pada perlakuan tanaman inang pisang dan diameter batang lebih dari $4 \mathrm{~cm}\left(\mathrm{ID}_{3}\right)$ dengan semua perlakuan. Pada perlakuan $\mathrm{ID}_{5}$ yaitu perlakuan dengan menggunakan tanaman inang terong dan aplikasi pada diameter batang antara $3 \mathrm{~cm}$ hingga $4 \mathrm{~cm}$, menunjukkan hasil pengaruh berbeda tidak nyata dengan semua perlakuan. Hal ini diduga bahwa inokulan yang diinjeksikan pada tanaman gaharu berdiameter lebih dari 4 $\mathrm{cm}$, menunjukkan adanya perlawanan tubuh tanaman terhadap serangan patogen dari luar tubuh tanaman. Sehingga membuat menurunnya kemampuan sel dari jaringan dalam melaksanakan fungsi-fungsi fisiologisnya (Sutrisno, 2011). Sumarna (2002) menyatakan infeksi yang disebabkan oleh fungi membuat penyumbatan di penyaluran tanaman sehingga menghasilkan senyawa resin berupa phytalyosin

Tabel 3 Hasil analisis minyak atsiri gaharu

\begin{tabular}{cc}
\hline Variabel Penelitian & Hasil Analisis \\
\hline Kadar minyak atsiri & \\
$(\mathrm{ppm})$ & $<100$ \\
\hline
\end{tabular}


Selain itu, perlakuan $\mathrm{ID}_{3}$ menjadi yang terbaik karena menurut Mukarlina, et. al., (2010) menyebutkan bahwa enzim-enzim yang terdapat di dalam cendawan Fusarium sp. dapat memecah bahan pektin yang ada di dalam dinding sel xilem. Sedangkan menurut Santoso (2007) menyatakan bahwa semakin besar diameter pohon maka semakin baik, karena memiliki volume gaharu yang dihasilkan semakin tinggi.

Gejala pembentukan gaharu akibat adanya isolat yang berperan didalam jaringan tanaman dinamakan browning (Santoso, et. al. 2007). Peristiwa browning yang terjadi pada batang tanaman gaharu yang terlihat pada gambar 4 yang telah diinokulasi terbentuk arah sebaran akibat infeksi dari inokulan memperlihatkan sebaran terpanjang mengarah vertikal dari pada ke arah horizontal. Hal ini diduga karena serangan patogen yang diinjeksikan kedalam tanaman, menginfeksi jaringan tanaman secara vertikal yang mengikuti arah pembuluh batang tanaman yang tersusun atas sel-sel vessel secara vertikal (Novriyanti, 2008).

Gambar 3 menunjukkan bahwasannya terdapat pengaruh perbedaan terhadap masing-masing perlakuan. Perubahan warna ini terjadi akibat adanya pelukaan karena pengeboran pada lubang inokulasi. Menurut Suhendra, et al (2012), menyatakan bahwa pelukaan jaringan disebabkan dapat secara alami ataupun secara sengaja dengan pengeboran dan penggergajian. Selain itu, diduga perubahan warna tersebut diakibatkan karena adanya senyawa asing atau mikroorganisme asing yang masuk kedalam tubuh tanaman. Proses infeksi tersebut terjadi karena proses fisiologis terbentuk gubal gaharu yang diawali dari masuknya mikroba penyakit ke dalam jaringan kayu, sehingga oleh tanaman mikroba tersebut dianggap sebagai benda asing yang terdapat di luar tubuh tanaman seperti halnya yang di kemukakan oleh Mega, dkk (2012). Menurut Subowo (2010) yang menyebabkan perubahan warna adalah adanya resin gaharu yang terakumulasi dalam rogga sel tanaman. Serta semakin lama resin yang terakumulasi, maka semakin banyak dan warna kayu akan menjadi coklat kehitaman.

Berdasarkan pada gambar 5, menunjukkan bahwa pada variabel tingkat aroma kemedangan gaharu tidak memberikan pengaruh yang signifikan pada semua perlakuan yang diujikan. Pada perlakuan $\mathrm{ID}_{3}$ menunjukkan nilai rata-rata perlakuan 1.87 , tetapi nilai tersebut menunjukkan tidak berbeda nyata dengan perlakuan $\mathrm{ID}_{1}$, $\mathrm{ID}_{2}, \mathrm{ID}_{8}$ dan $\mathrm{ID}_{9}$. Namun, berbeda nyata jika dibandingkan dengan $\mathrm{ID}_{4}, \mathrm{ID}_{5}, \mathrm{ID}_{6}$, dan $\mathrm{ID}_{7}$. Sehingga berdasarkan gambar 5 tersebut tingkat aroma kemedangan menunjukkan pengaruh yang tidak signifikan terhadap semua perlakuan yang diberikan. Hal ini diduga akibat kekuatan tubuh tanaman yang resisten terhadap serangan infeksi mikroba. Pernyataan tersebut sama halnya yang diungkapkan oleh Yunasfi, (2008) yang menyatakan bahwa virulensi pada suatu jenis patogen dapat berubah dari waktu ke waktu.

Selain itu, disebabkan pula karena waktu setelah inokulasi yang masih terlalu singkat sehingga batang tanaman yang terakumulasi oleh senyawa metabolit sekunder tidak terjadi pada semua bagian batang tanaman yang mengalami pelukaan. Seperti halnya yang dikemukakan oleh Herawati, et. al., (2010) menyebutkan proses produksi gaharu sangat ditentukan kuantitasnya oleh jumlah lubang atau luka yang diinokulasi dan kualitasnya tergantung dengan lamanya waktu sejak inokulasi hingga panen. Semakin lama maka semakin banyak resin wangi yang terakumulasi dan semakin tinggi kualitas gaharu yang dihasilkan.

Adanya penyebaran luas jaringan terinfeksi serta adanya perubahan warna kayu tersebut, maka terdapat senyawa-senyawa kimia yang keluar dari dalam tubuh tanaman dan senyawa tersebut tergolong ke dalam bagian minyak atsiri gaharu. Minyak atsiri tersebut, muncul akibat adanya mikroba yang masuk ke dalam jaringan tanaman sehingga tanaman tersebut mengeluarkan zat imun. Kadar minyak atsiri yang keluar pada tanaman G. versteegii dapat ditunjukkan pada hasil analisis pada Tabel 3.

Berdasarkan hasil analisis yang telah dilakukan, menunjukkan bahwa sampel batang gaharu yang di uji sebanyak < 100 ppm (25 ppm berdasarkan komunikasi pribadi). Hasil tersebut jika dikonversi dengan persen setara dengan $0,01 \%$. Rendahnya kadar minyak atsiri gaharu hasil inokulasi ini, diduga akibat tanaman penghasil gaharu yang digunakan memiliki diameter batang sangat kecil sehingga infeksi yang terjadi tidak terjadi pada seluruh bagian lubang inokulasi. Selain itu seperti yang telah dijelaskan sebelumnya, rendahnya kadar minyak atisiri ini juga patut diduga bahwa akibat dari waktu inokulasi yang masih kurang lama sehingga membuat infeksi yang terjadi akibat mikroba tersebut tidak berjalan maksimal. Berdasarkan hasil penelitian yang dilakukan oleh Herawati, et. al., (2010) menunjukkan bahwa umur gubal gaharu yang diinduksi 6 bulan mengandung zat ekstraktif sebanyak $20 \%$ sedangkan yang diinduksi 12 bulan $23.30 \%$.

\section{KESIMPULAN}

Hasil penelitian ini menunjukkan bahwa perlakuan cendawan Fusarium sp. Pada berbagai isolat memberikan pengaruh yang nyata terhadap pembentukan kemedangan gaharu pada berbagai diameter batang tanaman Gyrinophs versteegii. Perlakuan $\mathrm{ID}_{3}$ berpengaruh nyata pada variabel pengamatan luas jaringan terinfeksi dan warna jaringan terinfeksi. Perlakuan terbaik terjadi pada perlakuan $\mathrm{ID}_{3}$ yaitu isolat Fusarium sp. yang berasal dari tanaman pisang dapat membentuk kemedangan gaharu pada diameter batang tanaman G. versteegii lebih dari $4 \mathrm{~cm}$.

\section{DAFTAR PUSTAKA}

Agrios, G.N. 2004. Plant Pathology. Ed ke-5. California: Academic Press. Inc.

Hartatik, W., dan Setyorini, D. Tanpa Tahun. Pemanfaatan Pupuk Organik untuk Meningkatkan Kesuburan Tanah dan Kualitas Tanaman. Balai Penelitian Tanah. Bogor.

Herawati, C., R. Batubara., dan E.B.M. Siregar. 2010. Perubahan Kimia Kayu pada Gubal Gaharu. 117 125. 
Isnaini, Y. 2008. Peran Pelukaan Alami dalam Pembentukan Gubal Gaharu: Studi Kasus Pada Aquilaria malaccensis Lamk. Koleksi Kebun Raya Bogor. Buletin Kebun Raya Indonesia. Vol 11 (1): 36 - 40.

Mega, I.M., D.K. Suanda, D.N. Kasniari., W. Suena., dan M.A.O. Parwarata. 2012. Formulasi Inokulan Jamur Pembentuk Gubal Gaharu pada Tanaman Ketimunan (Gyrinophs versteegii). Agrotrop. 2(2):139-144.

Mukarlina, Khotimah, S., dan Rianti, R., 2010. Uji Antagonis Trichoderma harzianum Terhadap Fusarium spp. Penyebab Penyakit Layu pada Tanaman Cabai (Capsicum annum) Secara In Vitro. Fitomedika. 7 (2): $80-85$.

Novriayanti, E. 2008. Peranan Zat Ekstraktif dalam Pembentukan Gaharu Aquilaria crassna Pierre ex Lecomte dan Aquilaria microcarpa Baill. Institut Pertanian Bogor. 44 - 50.

Santoso, E., Agustini, L., Sitepu, I. R., dan Turjaman, M. 2007. Efektivitas Pembentukan Gaharu dan Komposisi Senyawa Resin Gaharu pada Aquilaria spp. Penelitian Hutan dan Konservasi Alam. 04 (06):543-551.

Subowo, Y.B. 2010. Jamur Pembentuk Gaharu Sebagai Penjaga Kelangsungan Hidup Tanaman Gaharu (Aquilaria sp.). J. Tek. Ling. Vol 11(2): 167 - 173.

Suhendra, A., Yuda, dan Dwi. 2012. Aplikasi Inokulasi Fusarium untuk Mempercepat Proses Pembentukan dan Produksi Gubal Gaharu di Kabupaten Penajam Paser Utara Kalimantan Timur. Prosiding Insinas.

Sumarna. 2002. Budidaya Gaharu, Seri Agribisnis. Jakarta: Penebar Swadaya.

Sumarna, Y. 2012. Budidaya Jenis Pohon Penghasil Gaharu. Bogor: Departemen Kehutanan.

Sutrisno, E. 2011. Inokulasi Jamur Fusarium sp. dalam Media Biakan Padat dan Cair Terhadap Pembentukan Gaharu pada Pohon Karas (Aquilaria malaccensis, Lamrk). $01-16$.

Syukur dan W. Muda. 2015. Gaharu dan Cara Penyuntikan Gubal Gaharu pada Pohon Gaharu. Balai Penelitian Jambi.

Jambi.. 